\title{
Professor Barrie Vernon-Roberts, AO, MD, BSc, PhD, FRCPath, FRCPA, FAOrthA (Hon), FRS.SA
}

\author{
K. D. Rainsford • D. R. Haynes
}

Received: 3 June 2013/ Accepted: 11 June 2013/Published online: 4 July 2013

(C) Springer Basel 2013

\begin{abstract}
This issue of Inflammopharmacology contains papers that have been submitted to commemorate the life and work of Professor Barrie Vernon-Roberts, an outstanding clinical scientist in the field of bone pathology and its pharmacological regulation. This review briefly summarizes his major works and achievements as well as a list of his publications.
\end{abstract}

This issue of Inflammopharmacology is dedicated to Professor Barrie Vernon-Roberts, one of the leading founding members of the Editorial Board of the Journal.

Indeed, he and Professor Michael Whitehouse were authors in the first issue of the journal in 1991 (Figs. 1, 2, 3 ) of a key article that featured significant and pioneering observations on the concept of "Conditional Pharmacology". To quote this concept concerns "the action and potency of a drug within the context of the whole syndrome to be treated. Endogenous factors (substances) are considered that might permit and/or augment the desired action of a drug (or even occasionally impede it). Such substances

Special issue: dedicated to the "Life and work of Professor Barrie Vernon-Roberts".

\section{K. D. Rainsford ( $\square)$}

Emeritus Professor, Biomedical Research Centre, Sheffield

Hallam University, Sheffield S1 1WB, UK

e-mail: k.d.rainsford@shu.ac.uk

\section{R. Haynes}

Discipline of Anatomy and Pathology School of Medical Sciences Division of Health Sciences, University of Adelaide, Frome Road, Adelaide, SA 5005, Australia

e-mail: david.haynes@adelaide.edu.au may be absent in healthy subjects or present in lower concentrations". (Whitehouse and Vernon-Roberts 1991). Thus, Conditional Pharmacology embraces the disease-> drug->disease interactions that may underlay a whole range of actions of drugs.

In a like manner Professor Vernon-Roberts has been a leading authority on many aspects of the mechanisms of inflammation and the drugs used to treat inflammatory conditions and cancer. His major speciality is recognized internationally as being in the pathology of bone, and notably the spine. Recognition of Professor Vernon-Roberts's outstanding contributions to spinal research was the

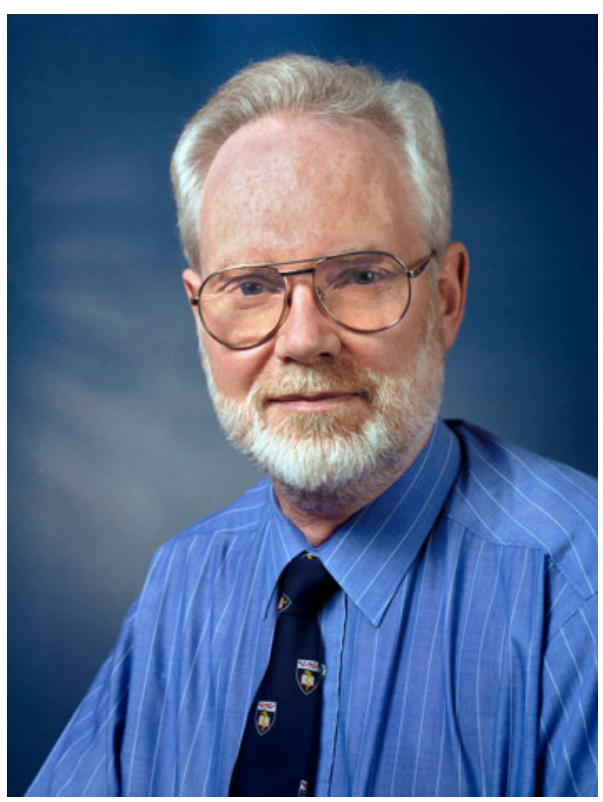

Fig. 1 Prof. Barrie Vernon-Roberts. Photograph kindly provided by Mr. Dale Caville (Discipline of Anatomy and Pathology, University of Adelaide) 


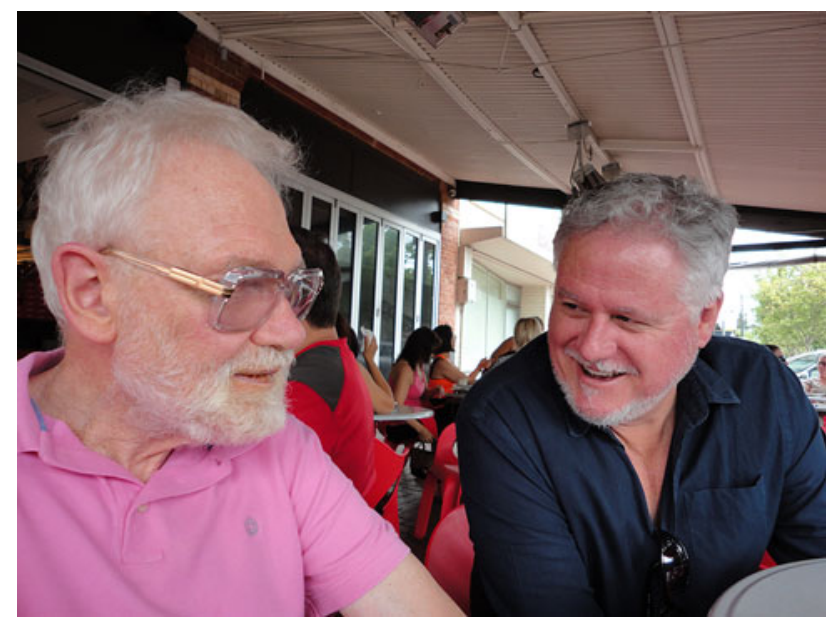

Fig. 2 A recent photograph of Prof. Vernon Roberts (left) with Assoc. Prof. David Haynes his long-standing collaborator and coeditor of this special issue

award in 2005 of the Inaugural Allan Dwyer Medal for a lifetime of excellence in spinal research awarded by the Spine Society of Australia (Prof Nigel Jones, www.spinesociety.org.au/node/119, downloaded 10/5/ 2013). He had previously been awarded the International Volvo Award in 1986 Low Back Pain Research. This award was for fundamental research examining degenerative disc changes in sheep in which discrete tears of the outer annulus of lumbar discs were shown to be important in degeneration of the intravertebral joint complex (Osti et al. 1990a). Some 26 additional awards that Professor Vernon-Roberts has received include recognition of his widespread research interests, notably studies on low back pain and lumbar inflammation and disc degeneration. He has also made major contributions to understanding of the pharmacological control of chronic inflammation in inflammatory cells and in the adjuvant arthritis animal model in vivo. His groundbreaking work on hip prosthesis loosening in identifying the role of macrophages causing bone loss and prosthesis failure due to wear particles from the prosthesis has had a significant impact on the field of Orthopaedics (Evans et al. 1974 and B. Vernon-Roberts, and M.A.R. Freeman, "The Tissue Response to Total Joint Replacement Prostheses", in The Scientific Basis of Joint Replacement, S.A.V Swanson, M.A.R. Freeman (eds.), Pitman Medical Publishing, Tunbridge Wells, Kent, UK, 1977, pp. 86-129). The extensive research in experimental models and elegant histopathological investigations of clinical material has demonstrated an extraordinary understanding of the pathogenesis of many diseases. These valuable observations and data on basic pathological processes give insight into the underlying inflammatory and immunological changes involved in joint destruction in a variety of conditions.
The ultimate accolade was the award to Professor Vernon-Roberts of the Officer of the Order of Australia (AO) in the General Discussion in the Queen's Birthday Honours in 2005. This award was given "for service to medicine as a researcher, education and administrator, particularly in the areas of disorders of the bones and joints and pathology of the spine".

Professor Vernon-Roberts was born in North Wales and educated at Ruthin School (established as a private school for boys in 1284) at Ruthin, Clwyd (near Wrexham in North Wales). He studied medicine at the Charing Cross Hospital Medical School and received the MB, BS degree of the University of London in 1960. He received several undergraduate prizes and was awarded the Llewellyn Scholarship as an outstanding medical graduate. After internships at Charing Cross Hospital he had a Lectureship at King's College, University of London. He undertook research on sex and other hormonal regulation of macrophages for which he received a $\mathrm{PhD}$ in 1965 and an MD in 1966. He was then invited by Cambridge University Press on the basis of this.

Research on macrophages to write a major book on the macrophage which was published in 1972 (242 pp, ISBN: 0521084814). He was appointed a Senior Lecturer and Consultant Pathologist at the Royal London Hospital Medical College in 1974. Then he established a collaborative research centre, the Arthritis and Rheumatism Council's Bone and Joint Research Unit, of which he became its Director. In 1976 he was appointed to the prestigious post of the George Richard Marks Professor of Pathology at the University of Adelaide Medical School, Adelaide, South Australia, as well as Head of the Division of Tissue Pathology at the Institute of Medical and Veterinary Science (IMVS) and Senior Visiting Pathologist at the Royal Adelaide Hospital (RAH). In 1997 he was appointed Deputy Director and Chief Pathologist at the IMVS and in 1998 was appointed Director and Chief Executive of the IMVS. This institute was originally founded in 1938 by an eminent physician, Sir Trent Champion de Crespigny who had been Medical Superintendent of the RAH and Dean of Medicine at the University of Adelaide in the period from 1929 to 1947 (Kearney 1997). He had the inspired vision for an institute combining laboratory services with teaching and research. The IMVS became a world-renown clinically based medical and veterinary research institution and has been known for many major discoveries of clinically important diseases and their treatment. Prof Vernon-Roberts was instrumental in redefining the focus and development of the IMVS including the establishment in 1991 of the Hanson Institute (formerly the Hanson Centre for Cancer Research funded originally by the South Australian Anticancer Foundation). This became the research division of the IMVS housed in superb 
Fig. 3 Front page of article on conditional pharmacology by Whitehouse and Vernon-

Roberts (1991)
Inflammopharmacology. 1991;1:61-68.

Copyright $(\mathcal{O}$ Kluwer Academic Publishers bv - Printed in the Netherlands

\section{CONDITIONAL PHARMACOLOGY: EXPRESSION OF ANTI-INFLAMMATORY ACTIVITY MAY REQUIRE PRE-EXISTENT INFLAMMATORY MEDIATORS AND/OR HORMONES}

\author{
M.W. WHITEHOUSE AND B. VERNON-ROBERTS \\ Department of Pathology, University of Adelaide, Adelaide, South Australia 5001, \\ Australia
}

\begin{abstract}
Whitehouse MW, Vernon-Roberts B. Conditional pharmacology: expression of anti-inflammatory activity may require pre-existent inflammatory mediators and/or hormones. Inflammopharmacology. 1991;1: 61-68

Aspirin, aminopyrine, azapropazone, bufexamac $(100 \mathrm{mg} / \mathrm{kg})$, and even high doses of copper acetate $(50 \mathrm{mg} / \mathrm{kg}$ p.o.) showed no acute anti-inflammatory activity in the standard assay based on the carrageenan-induced rat paw oedema in healthy, normal rats. Repeating the assays in animals with pre-established inflammation revealed that these drugs are effective anti-oedemic agents. The acceptability of these agents in clinical practice may therefore rest on the fact that certain inflammatory mediators can support and/or induce the expression of an anti-inflammatory activity of agents, that are ineffective in animals not affected by additional inflammations. If misoprostol (a prostaglandin- $\mathrm{E}_{1}$ analogue) is given p.o. together with the above test-drugs to healthy rats, the anti-oedemic properties of these drugs are revealed, suggesting that prostanoids may potentiate some of the NSAIDs which do not inhibit prostanoid synthesis per se.
\end{abstract}

Keywords: Copper, aspirin, aminopyrine, azapropazone, anti-oedemic, bufexamac, misoprostol

\section{INTRODUCTION}

Several drugs continue to be used clinically to treat inflammatory disorders and associated pain, even though they show little or no significant anti-inflammatcry activity in some 'acute' pharmacological assays. Examples include aminopyrine (4-dimethylamino-phenazone), also known as amidopyrine or pyramidone [1], azapropazone [2], bufexamac [3] and the simple salicylates [4]. One explanation is that the pharmacological assays used may be too blunt, or even inappropriate, for detecting a response to these drugs (assuming they are indeed anti-inflammatory). Another explanation might be that such drugs are merely analgesics, and it is this property which sustains patient demand and their extensive usage. This report indicates that these particular drugs probably possess anti-inflammatory properties and that one traditional 'rapid' pharmacological assay, utilizing suppression of carrageenan-induced paw oedema in rats, can be readily adapted to reveal the effects of drugs hitherto found to be inactive. This has important ramifications for preclinical testing and for an understanding of ways in which a disease process may work with, or against, a drug [5]. laboratories with world-class researchers in Centres for Cancer Research, Bone and Joint Research, Clinical Research, Neurological Diseases and Biomedical Research (www.hansoninstitute.sa.gov/aboutus/history.phr; downloaded 12/5/2013). The Adelaide Centre for Spinal Research was one of the research centres of the Hanson
Institute whose development was actively supported by Prof. Vernon-Roberts whose pioneering research on spinal conditions has formed the basis of major contributions to research by this centre.

His research has been supported by leading competitive grant agencies (e.g. including the Australian National 
Health and Medical Research Council) to the extent of over \$AU15 m over the years. He was an active member of a large number of peer-reviewing grant committees and agencies in Australia and was a senior administrative officer of the University of Adelaide including being ProVice Chancellor, Vice-Dean of the Faculty of Medicine. He was also an executive member of several Boards, Foundations and Councils involved in public health, medical research and professional bodies in Australia. He retired from the University of Adelaide and the IMVS in 2005 after completing his term as Director of the IMVS and is currently Senior Consultant Pathologist at the Adelaide Centre for Spinal Research and an Emeritus Professor of the University of Adelaide.

Professor Vernon-Roberts also inspired and educated a large number of research students and researchers that now make important impacts in their field. The publications in this special issue are contributions from some of Professor Vernon-Roberts' collaborators and past students that cover the wide spectrum of his interests. The Editors are most grateful to these authors for their valuable contributions.

\section{Appendix: A personal appreciation of Professor Barrie Vernon-Roberts}

Professor Vernon-Roberts was an early supporter of neuropathology as a specialty at the Institute of Medical and Veterinary Science (now part of SA Pathology), the major provider of public and private pathology services in the state of South Australia. Since neuropathology has been my longstanding research interest, I have benefited greatly from this support. He also founded the Hanson Institute Centre for Neurological Diseases at this institution in 2004 and, under the leadership of Professor Peter Blumbergs, the Centre has become the major focus for diagnostic pathology and research in this field in the State. One of the Centre's main strengths is traumatic brain injury (TBI) and Professor Vernon-Roberts helped to foster this activity from the early stages. I have had a long association with the Centre, principally assisting with the development of animal models of TBI. Using his dual appointment as Professor of Pathology at the University of Adelaide and Head of Tissue Pathology (and later Director) at IMVS, Barrie strengthened the nexus between these institutions and many postgraduate students have benefited as a result. He facilitated, for example, my interest in ultrastructural pathology, which led to a higher degree in this area. A tangible legacy of Professor Vernon-Robert's support for neurological disease research is the continuing close relationship between the University's School of Medical Sciences (under Professor Robert Vink) and the Centre for Neurological Diseases. He also recognised the important role of veterinary services in a biomedical research institution such as the IMVS and this support allowed me to pursue my interest in veterinary diagnostic and investigative pathology. Barrie was always available to discuss bone and joint pathology over a double-head microscope and share his vast knowledge in this specialised field. His tenure as Director of the IMVS is widely recognised as being one of the most productive and innovative periods in its long history.

Dr John Finnie

Senior Veterinary Pathologist

SA Pathology

\section{References}

\section{Publications by Prof. Vernon-Roberts}

Listed below are the published works of Professor Vernon-Roberts based on available information. The inclusion of these is intended to be a comprehensive account of his research work. An interesting compilation of biographical cutting and references in media referring to reports of his activities and articles can be found in a book at the National Library of Australia details of which are as follows:

"Bibliographical cuttings on Barrrie Vernon-Roberts, Professor of Pathology and Chairman of the Anti-Cancer Foundation, containing one or more cuttings from newspapers or journals". Bibliographic ID: 553876

Citation: http://catalogue.nla.gov.au/Record/553876 [downloaded 10/5/ 2013]

Awerbuch MS, Brooks PM, Vernon-Roberts B (1981) Calcific tendinitis at multiple sites. Med J Aust 1:189-190

Awerbuch MS, Shephard E, Vernon-Roberts B (1982) Morton's metatarsalgia due to intermetatarsophalangeal bursitis as an early manifestation of rheumatoid arthritis. Clin Orthop Relat Res 167:214-221

Barnardo DE, Vernon-Roberts B, Currey HL (1973) A case of active chronic hepatitis with painless erosive arthritis. Gut 14:800-804

Barnes CG, Turnbull AL, Vernon-Roberts B (1971) Felty's syndrome. A clinical and pathological survey of 21 patients and their response to treatment. Ann Rheum Dis 30:359-374

Bartold PM, Hay S, Vernon-Roberts B (1989a) Effect of cyclosporine-A on connective tissue deposition in experimental inflammatory lesions. Matrix 9:293-300

Bartold PM, Haynes DR, Vernon-Roberts B (1989b) Effect of mitogen and lymphokine stimulation on proteoglycan synthesis by lymphocytes. J Cell Physiol 140:82-90

Baskaran S, Blumbergs PC, Jones N, Vernon-Roberts B (1996) Chondromatosis of the choroid plexus. J Clin Neurosci 3:82-84

Berlemann U, Gries NC, Moore RJ, Fraser RD, Vernon-Roberts B (1998) Calcium pyrophosphate dihydrate deposition in degenerate lumbar discs. Eur Spine J 7:45-49

Betts WH, Whitehouse MW, Cleland LG, Vernon-Roberts B (1985) In vitro antioxidant properties of potential biotransformation products of salicylate, sulphasalazine and amidopyrine. J Free Radic Biol Med 1:273-280

Beveridge SJ, Garrett IR, Whitehouse MW, Vernon-Roberts B, Brooks PM (1985) Biodistribution of $64 \mathrm{Cu}$ in inflamed rats 
following administration of two anti-inflammatory copper complexes. Agents Actions 17:104-111

Blackwell JB, McCarthy SW, Xipell JM, Vernon-Roberts B, Duhig RE (1988) Osteofibrous dysplasia of the tibia and fibula. Pathology 20:227-233

Brooks PM, Garrett R, Whitehouse MW, Vernon-Roberts B (1984) Effects of aspirin and isoxicam alone and in combination on poly urethane sponge implantation model in the rat. Aust NZ J Med $14: 359$

Brooks PM, Vernon-Roberts B, Manthey B, Garrett R (1982) Interactions of non-steroidal anti-inflammatory drugs (NSAIDs) on acute inflammation using the polyurethane sponge implantation model in rats. Clin Res 30:A651

Clarke AK, Vernon-Roberts B, Currey HL (1975) Assessment of antiinflammatory drugs in the rat using subcutaneous implants of polyurethane foam impregnated with dead tubercle bacilli. Ann Rheum Dis 34:326-331

Cleland LG, Betts WH, Vernon-Roberts B, Bielicki J (1982) Role of iron and influence of antiinflammatory drugs on oxygen-derived free radical production and reactivity. J Rheumatol 9:885-892

Cleland LG, Vernon-Roberts B, Smith K (1984) Fibre glass induced synovitis. Ann Rheum Dis 43:530-534

Cleland LG, Whitehouse MW, Betts WH, Vernon-Roberts B (1985) Diphenols and aminophenols with antioxidant properties in vitro-in vivo correlations. Aust NZ J Med 15:193

Collins PC, Paterson DC, Vernon-Roberts B, Pfeiffer D (1981a) Bone formation and impedance of electrical current flow. Clin Orthop Relat Res 155:196-210

Collins P, Paterson DC, Vernon-Roberts B, Pfeiffer D (1981b) Bone growth and impedence their relationship during electrical stimulation. Aus NZ J Med 51:391

Crane GJ, Fazzalari NL, Parkinson IH, Vernon-Roberts B (1990) Age-related changes in femoral trabecular bone in arthrosis. Acta Orthop Scand 61:421-426

Darracott J, Vernon-Roberts B (1971) The bony changes in "chondromalacia patellae". Rheumatol Phys Med 11:175-179

Darracott J, Vernon-Roberts B (1973) Chondromalacia patellae. Br Med J 1:491-492

Darracott J, Vernon-Roberts B, Pazzalari N (1982) Bone failure in osteo arthritis of the femoral head. Arth Rheum 25:S44

Darracott J, Vernon-Roberts B, Fazzalari N (1981) Bone changes in osteoarthritis of the hip. Aus NZ J Med 11:714

David DJ, Speculand B, Vernon-Roberts B, Sach RP (1978) Malignant schwannoma of the inferior dental nerve. Br J Plast Surg 31:323-333

Dean MF, Muir H, Marshall AH, Revell PA, Vernon-Roberts B (1971) Proteoglycans from sheep, pig, rat and human spleens having chemical and biological resemblances to that in Kurloff cells. FEBS Lett 16:183-185

Dewar AL, Farrugia AN, Condina MR, Bik To L, Hughes TP, Vernon-Roberts B, Zannettino AC (2006) Imatinib as a potential antiresorptive therapy for bone disease. Blood 107:4334-4337

Dore JL, Vernon-Roberts B (1976) A method for the selective demonstration of gold in tissue sections. Med Lab Sci 33:209-213

Durbridge TC, Morris HA, Parsons AM, Parkinson IH, Moore RJ, Porter S, Need AG, Nordin BE, Vernon-Roberts B (1990) Progressive cancellous bone loss in rats after adrenalectomy and oophorectomy. Calcif Tissue Int 47:383-387

Evans EM, Freeman MA, Miller AJ, Vernon-Roberts B (1974) Metal sensitivity as a cause of bone necrosis and loosening of the prosthesis in total joint replacement. J Bone Joint Surg Br 56-B: $626-42$

Fagan A, Moore R, Vernon Roberts B, Blumbergs P, Fraser R (2003) ISSLS prize winner: the innervation of the intervertebral disc: a quantitative analysis. Spine (Phila Pa 1976) 28:2570-2576
Fagan AB, Sarvestani G, Moore RJ, Fraser RD, Vernon-Roberts B, Blumbergs PC (2010) Innervation of anulus tears: an experimental animal study. Spine (Phila Pa 1976) 35:1200-1205

Fazzalari NL, Costi JJ, Hearn TC, Fraser RD, Vernon-Roberts B, Hutchinson J, Manthey BA, Parkinson IH, Sinclair C (2001) Mechanical and pathologic consequences of induced concentric anular tears in an ovine model. Spine (Phila Pa 1976) 26:2575-2581

Fazzalari NL, Darracott J, Vernon-Roberts B (1985) Histomorphometric changes in the trabecular structure of a selected stress region in the femur in patients with osteoarthritis and fracture of the femoral neck. Bone 6:125-133

Fazzalari NL, Darracott J, Vernon-Roberts B (1983-1984) A quantitative description of selected stress regions of cancellous bone in the head of the femur using automatic image analysis. Metab Bone Dis Relat Res 5: 119-25

Fazzalari NL, Crisp DJ, Vernon-Roberts B (1989a) Mathematical modelling of trabecular bone structure: the evaluation of analytical and quantified surface to volume relationships in the femoral head and iliac crest. J Biomech 22:901-910

Fazzalari NL, Moore RJ, Manthey BA, Vernon-Roberts B (1989b) Comparative study of iliac crest and proximal femur histomorphometry in normal patients. J Clin Pathol 42:745-748

Fazzalari NL, Moore RJ, Manthey BA, Vernon-Roberts B (1992) Comparative study of iliac crest and subchondral femoral bone in osteoarthritic patients. Bone 13:331-335

Fazzalari NL, Vernon-Roberts B, Darracott J (1987) Osteoarthritis of the hip. Possible protective and causative roles of trabecular microfractures in the head of the femur. Clin Orthop Relat Res 216:224-233

Finnie JW, Blumbergs PC, Manavis J, Utteridge TD, Gebski V, Davies RA, Vernon-Roberts B, Kuchel TR (2002) Effect of long-term mobile communication microwave exposure on vascular permeability in mouse brain. Pathology 34:344-347

Finnie JW, Blumbergs PC, Manavis J, Utteridge TD, Gebski V, Swift JG, Vernon-Roberts B, Kuchel TR (2001) Effect of global system for mobile communication (gsm)-like radiofrequency fields on vascular permeability in mouse brain. Pathology 33:338-340

Fitter S, Dewar AL, Kostakis P, To LB, Hughes TP, Roberts MM, Lynch K, Vernon-Roberts B, Zannettino AC (2008) Long-term imatinib therapy promotes bone formation in CML patients. Blood 111:2538-2547

Fraser R, Vernon-Roberts B, Ost OL (1996) Iatrogenic discitis. In: Wiesel SW, Weinstein JN (eds) The Lumbar Spine, pp 899-916

Fraser RD, Osti OL, Vernon-Roberts B (1987) Discitis after discography. J Bone Joint Surg Br 69:26-35

Fraser RD, Osti OL, Vernon-Roberts B (1986) Discitis following chemonucleolysis. An experimental study. Spine (Phila Pa 1976) 11:679-687

Fraser RD, Osti OL, Vernon-Roberts B (1989) Iatrogenic discitis: the role of intravenous antibiotics in prevention and treatment. An experimental study. Spine (Phila Pa 1976) 14:1025-1032

Fraser RD, Osti OL, Vernon-Roberts B (1993) Intervertebral disc degeneration. Eur Spine J 1:205-213

Garrett R, Manthey B, Vernon-Roberts B, Brooks PM (1983a) Assessment of nonsteroidal anti-inflammatory drug combinations by the polyurethane sponge implantation model in the rat. Ann Rheum Dis 42:439-442

Garrett R, Wilksch J, Vernon-Roberts B (1983b) Effects of cobaltchrome alloy wear particles on the morphology, viability and phagocytic activity of murine macrophages in vitro. Aust J Exp Biol Med Sci 61(Pt 3):355-369

Garrett IR, Whitehouse MW, Vernon-Roberts B, Brooks PM (1985a) Ambivalent properties of gold drugs in adjuvant induced polyarthritis in rats. J Rheumatol 12:1079-1082 
Garrett IR, Haynes D, Vernon-Roberts B (1985b) Gold complexes and macrophage FC receptor binding. Aust NZ J Med 15:184

Garrett IR, Haynes D, Vernon-Roberts B (1985c) Levels of superoxide radical production by macrophages from rats treated with and without gold compounds. Aust NZ J Med 15:185

Garrett R, Manthey B, Vernon-Roberts B, Brooks PM (1986) The effect of isoxicam-aspirin combinations on the polyurethane sponge implantation model in the rat. $\mathrm{Br} \mathrm{J}$ Clin Pharmacol 22(Suppl 2):125S-128S

Garrett IR, Hay S, Vernon-Roberts B, Cleary EG, Wiebkin OW, Brooks PM, Manthey B (1984) The influence of prednisolone and methotrexate on the collagen and proteo glycan content of subcutaneously implanted poly urethane sponges in rats. Aust NZ J Med 14:361

Garrett R, Vernon-Roberts B, Brooks PM, Manthey B (1981) Effects of high-low dose combinations of aspirin and other NSAID on the inflammatory response assessed by polyurethane sponge implantation. Aus NZ J Med 11:718

Gerber N, Vernon-Roberts B (1977) Polymyalgia rheumatica. Clinical histological study of 46 cases. Z Rheumatol 36:275-284

Ghosh P, Moore R, Vernon-Roberts B, Goldschlager T, Pascoe D, Zannettino A, Gronthos S, Itescu S (2012) Immunoselected STRO-3+ mesenchymal precursor cells and restoration of the extracellular matrix of degenerate intervertebral discs. J Neurosurg Spine 16:479-488

Gries NC, Berlemann U, Moore RJ, Vernon-Roberts B (2000) Early histologic changes in lower lumbar discs and facet joints and their correlation. Eur Spine J 9:23-29

Gunzburg R, Fraser RD, Moore R, Vernon-Roberts B (1993) An experimental study comparing percutaneous discectomy with chemonucleolysis. Spine(Phila Pa 1976) 18:218-226

Gunzburg R, Parkinson R, Moore R, Cantraine F, Hutton W, VernonRoberts B, Fraser R (1992) A cadaveric study comparing discography, magnetic resonance imaging, histology, and mechanical behavior of the human lumbar disc. Spine (Phila Pa 1976) 17:417-426

Hay S, Garrett IR, Vernon-Roberts B, Cleary EG, Manthey B, Brooks PM (1986) Influence of prednisolone and methotrexate on cellular and biochemical aspects of acute and chronic inflammation studied in subcutaneously implanted sponges in rats. J Rheumatol 13:1007-1013

Haynes DR, Boyle SJ, Rogers SD, Howie DW, Vernon-Roberts B (1998a) Variation in cytokines induced by particles from different prosthetic materials. Clin Orthop Relat Res 352:223230

Haynes DR, Hutchens MJ, Whitehouse MW, Vernon-Roberts B (1998b) A comparison of the disease-modifying and cytokineregulating activities of tenidap, piroxicam and cyclosporin-A using the adjuvant-induced model of arthritis in rats. Inflammopharmacology 6:193-202

Haynes DR, Gadd SJ, Whitehouse MW, Mayrhofer G, VernonRoberts B (1996a) Complete prevention of the clinical expression of adjuvant-induced arthritis in rats by cyclosporin-A and lobenzarit: the regulation of lymph node cell populations and cytokine production. Inflamm Res 45:159-165

Haynes DR, Rogers SD, Howie DW, Pearcy MJ, Vernon-Roberts B (1996b) Drug inhibition of the macrophage response to metal wear particles in vitro. Clin Orthop Relat Res 323:316-326

Haynes DR, Garrett IR, Vernon-Roberts B (1988a) Effect of gold salt treatment on the receptor binding activity of monocytes and macrophages isolated from rats with adjuvant arthritis. Rheumatol Int 8:159-164

Haynes DR, Garrett IR, Whitehouse MW, Vernon-Roberts B (1988b) Do gold drugs inhibit interleukin-1? Evidence from an in vitro lymphocyte activating factor assay. J Rheumatol 15:775-778
Haynes DR, Whitehouse MW, Vernon-Roberts B (1991) The effects of some anti-arthritic drugs and cytokines on the shape and function of rodent macrophages. Int J Exp Pathol 72:9-22

Haynes DR, Whitehouse MW, Vernon-Roberts B (1992) The prostaglandin E1 analogue, misoprostol, regulates inflammatory cytokines and immune functions in vitro like the natural prostaglandins E1, E2 and E3. Immunology 76:251-257

Haynes DR, Wright PF, Gadd SJ, Whitehouse MW, Vernon-Roberts B (1993) Is aspirin a prodrug for antioxidant and cytokinemodulating oxymetabolites? Agents Actions 39:49-58

Haynes DR, Wright PF, Whitehouse MW, Vernon-Roberts B (1990) The cyclo-oxygenase inhibitor, piroxicam, enhances cytokineinduced lymphocyte proliferation in vitro and in vivo. Immunol Cell Biol 68(Pt 4):225-230

Haynes DR, Vernon-Roberts B (1995) Potential pharmacological treatments of prosthetic joint loosening. Inflammopharmacol 3:213-219

Helal B, Currey HL, Vernon-Roberts B (1974) Fibrous histiocytoma of the thumb. Br J Surg 61:909-910

Helal B, Vernon-Roberts B (1976) Intraosseous ganglion of the pisiform bone. Hand 8:150-154

Hirsch RS, McClure J, Vernon-Roberts B (1984) Induction and characterisation of local (simple) calcergy in granulation tissue in the rat by lead acetate injection into polyurethane sponges. Aust J Exp Biol Med Sci 62(Pt 6):727-742

Hirsch RS, McClure J, Vernon-Roberts B, Smith K (1985a) A study of calcergy in the rat induced by the implantation of polyurethane sponges soaked in lead acetate. Aust J Exp Biol Med Sci 63(Pt 2):249-260

Hirsch RS, Smith K, Vernon-Roberts B (1985b) A morphological study of macrophage and synovial cell interactions with hydroxyapatite crystals. Ann Rheum Dis 44:844-851

Hirsch RS, McClure J, Vernon-Robertws B (1983) Induction and characterization of experimental calcification in rats. J Dent Res 62:679

Howie DW, Cornish BL, Vernon-Roberts B (1990) Resurfacing hip arthroplasty. Classification of loosening and the role of prosthesis wear particles. Clin Orthop Relat Res 255:144-159

Howie DW, Cornish BL, Vernon-Roberts B (1993a) The viability of the femoral head after resurfacing hip arthroplasty in humans. Clin Orthop Relat Res 291:171-184

Howie DW, Manthey B, Hay S, Vernon-Roberts B (1993b) The synovial response to intraarticular injection in rats of polyethylene wear particles. Clin Orthop Relat Res 292:352-357

Howie DW, Vernon-Roberts B (1988a) Long-term effects of intraarticular cobalt-chrome alloy wear particles in rats. J Arthroplasty 3:327-336

Howie DW, Vernon-Roberts B (1988b) Synovial macrophage response to aluminium oxide ceramic and cobalt-chrome alloy wear particles in rats. Biomaterials 9:442-448

Howie DW, Vernon-Roberts B (1988c) The synovial response to intraarticular cobalt-chrome wear particles. Clin Orthop Relat Res 232:244-254

Howie DW, Vernon-Roberts B, Oakeshott R, Manthey B (1988) A rat model of resorption of bone at the cement-bone interface in the presence of polyethylene wear particles. J Bone Joint Surg Am 70:257-263

Inoue A, Freeman MA, Vernon-Roberts B, Mizuno S (1976) The pathogenesis of Perthes' disease. J Bone Joint Surg $\mathrm{Br}$ 58-B:453-461

Jessop JD, Vernon-Roberts B, Harris J (1973) Effects of gold salts and prednisolone on inflammatory cells. I. Phagocytic activity of macrophages and polymorphs in inflammatory exudates studied by a "skin-window" technique in rheumatoid and control patients. Ann Rheum Dis 32:294-300 
Jessop JD, Vernon-Roberts B, Harris J (1972) Phagocytic activity of macrophages and polymorphs in inflammatory exudates studied by a 'skin window' technique in rheumatoid and control patients. Ann Rheum Dis 31:535-536

Kearney BJ (1997) The Institute of Medical and Veterinary Science. Med J Aust 167:614-617

Klestov AC, Webb J, Vernon-Roberts B, Lomax-Smith J (1980) Minor salivary gland histology in rheumatoid arthritis and osteo arthritis. Arth Rheum 23:704

Koszyca B, Fazzalari NL, Vernon-Roberts B (1990) Microfractures in coxarthrosis. Acta Orthop Scand 61:307-310

Koszyca B, Fazzalari NL, Vernon-Roberts B (1989) Trabecular microfractures. Nature and distribution in the proximal femur. Clin Orthop Relat Res 244:208-216

Krajewska I, Vernon-Roberts B, Sorby-Adams G (1988) Parosteal (periosteal) lipoma. Pathology 20:179-183

Langman J, Rowland R, Vernon-Roberts B (1981) Endometriosis of the appendix. Br J Surg 68:121-124

Langman JM, Fazzalari NL, Rowland R, Vernon-Roberts B (1986) Lymphoid aggregates in the guinea pig large bowel: development of quantitation techniques for number, volume and distribution. Aust J Exp Biol Med Sci 64(Pt 1):11-17

Langman JM, Rowland R, Vernon-Roberts B (1985) Carrageenan colitis in the guinea pig: pathological changes and the importance of ascorbic acid deficiency in disease induction. Aust J Exp Biol Med Sci 63(Pt 5):545-553

Latham JM, Pearcy MJ, Costi JJ, Moore R, Fraser RD, VernonRoberts B (1994) Mechanical consequences of annular tears and subsequent intervertebral disc degeneration. Clin Biomech 9:211-219

Liyanage SP, Currey HL, Vernon-Roberts B (1975) Influence of tubercle aggregate size on severity of adjuvant arthritis in the rat. Ann Rheum Dis 34:49-53

Liyanage SP, Currey HL, Vernon-Roberts B (1974) Proceedings: influence of tubercle aggregate size on the severity of adjuvant arthritis in the rat. Ann Rheum Dis 33:401

Lowthian PJ, Cleland LG, Vernon-Roberts B (1984) Hepatotoxicity with aurothioglucose therapy. Arthritis Rheum 27:230-232

Magarey CJ, Baum M, Mackay WD, Quantock DC, Vernon-Roberts B (1968) Cancer and its treatments, and the reticulo-endothelial system in man. Br J Surg 55:872

Marshall AH, Swettenham KV, Vernon-Roberts B (1970) The function of the Kurloff cell and its possible relation to the immunological status of the guinea-pig placenta. J Anat 106:414-415

Marshall AH, Swettenham KV, Vernon-Roberts B, Revell PA (1971) Studies on the function of the Kurloff cell. Int Arch Allergy Appl Immunol 40:137-152

McColl SR, Cleland LG, Whitehouse MW, Vernon-Roberts B (1987) Effect of dietary polyunsaturated fatty acid (PUFA) supplementation on adjuvant induced polyarthritis in rats. J Rheumatol 14:197-201

McNeil JD, Wiebkin OW, Cleland LG, Vernon-Roberts B (1986) The generation of reducing ends by exposure of hyaluronic acid to oxygen derived free radicals. Agents Actions Suppl 18:95-101

McNeil JD, Whitehouse MW, Quin MA, Cleland LG, VernonRoberts B (1985) Oleyl alcohol is a potent inflammogen in both the rat paw and the rabbit knee. Aus NZ J Med 15:191

Melrose J, Ghosh P, Taylor TK, Hall A, Osti OL, Vernon-Roberts B, Fraser RD (1992) A longitudinal study of the matrix changes induced in the intervertebral disc by surgical damage to the annulus fibrosus. J Orthop Res 10:665-676

Melrose J, Ghosh P, Taylor TK, Vernon-Roberts B, Latham J, Moore R (1997) Elevated synthesis of biglycan and decorin in an ovine annular lesion model of experimental disc degeneration. Eur Spine J 6:376-384
Melrose J, Smith SM, Little CB, Moore RJ, Vernon-Roberts B, Fraser RD (2008) Recent advances in annular pathobiology provide insights into rim-lesion mediated intervertebral disc degeneration and potential new approaches to annular repair strategies. Eur Spine J 17:1131-1148

Moore RJ, Durbridge TC, McNeil PJ, Parkinson IH, Need AG, Vernon-Roberts B (1992a) Trabecular spacing in postmenopausal Australian women with and without vertebral fractures. Aus NZ J Med 22:269-273

Moore RJ, Durbridge TC, McNeil PJ, Parkinson IH, Need AG, Vernon-Roberts B (1992b) Trabecular spacing in post-menopausal Australian women with and without vertebral fractures. Aust N Z J Med 22:269-273

Moore RJ, Osti OL, Vernon-Roberts B, Fraser RD (1992c) Changes in endplate vascularity after an outer anulus tear in the sheep. Spine (Phila Pa 1976) 17:874-878

Moore RJ, Crotti TN, Osti OL, Fraser RD, Vernon-Roberts B (1999) Osteoarthrosis of the facet joints resulting from anular rim lesions in sheep lumbar discs. Spine (Phila Pa 1976) 24: $519-525$

Moore RJ, Durbridge TC, Woods AE, Vernon-Roberts B (1989a) Comparison of two bone trephine instruments used for quantitative histomorphometry. J Clin Pathol 42:213-215

Moore RJ, Durbridge TC, Woods AE, Vernon-Roberts B (1989b) Variation in histomorphometric estimates across different sites of the iliac crest. J Clin Pathol 42:814-816

Moore RJ, Fazzalari NL, Manthey BA, Vernon-Roberts B (1994a) The relationship between head-neck-shaft angle, calcar width, articular cartilage thickness and bone volume in arthrosis of the hip. Br J Rheumatol 33:432-436

Moore RJ, Latham JM, Vernon-Roberts B, Fraser RD (1994b) Does plate fixation prevent disc degeneration after a lateral anulus tear? Spine (Phila Pa 1976) 19:2787-2790

Moore RJ, Fraser RD, Vernon-Roberts B, Finnie JW, Blumbergs PC, Haynes DR, Hutchens MJ, Walters RM, Kamat AS, Koszyca B (2002) The biologic response to particles from a lumbar disc prosthesis. Spine (Phila Pa 1976) 27:2088-2094

Moore RJ, Vernon-Roberts B, Fraser RD, Osti OL, Schembri M (1996a) The origin and fate of herniated lumbar intervertebral disc tissue. Spine (Phila Pa 1976) 21:2149-2155

Moore RJ, Vernon-Roberts B, Osti OL, Fraser RD (1996b) Remodeling of vertebral bone after outer anular injury in sheep. Spine (Phila Pa 1976) 21:936-940

Nicol T, Bilbey DL, Charles LM, Cordingley JL, Vernon-Roberts B (1964) Oestrogen: the natural stimulant of body defence. J Endocrinol 30:277-291

Nicol T, Quantock DC, Vernon-Roberts B (1966a) Stimulation of phagocytosis in relation to the mechanism of action of adjuvants. Nature 209:1142-1143

Nicol T, Vernon-Roberts B, Quantock DC (1966b) Effect of orchidectomy and ovariectomy on survival against lethal infections in mice. Nature 211:1091-1092

Nicol T, Vernon-Roberts B, Quantock DC (1966c) The effect of various anti-oestrogenic compounds on the reticulo-endothelial system and reproductive tract in the ovariectomized mouse. J Endocrinol 34:377-386

Nicol T, Vernon-Roberts B, Quantock DC (1966d) The effects of oestrogen: androgen interaction on the reticulo-endothelial system and reproductive tract. J Endocrinol 34:163-178

Nicol T, Vernon-Roberts B, Quantock DC (1966e) Oestrogenic and anti-oestrogenic effects of oestriol, 16-epi-oestriol, 2-methoxyoestrone and 2-hydroxyoestradiol-17 beta on the reticuloendothelial system and reproductive tract. $\mathrm{J}$ Endocrinol 35:119-120

Nicol T, Vernon-Roberts B, Quantock DC (1967) The effect of testosterone and progesterone on the response of the reticulo- 
endothelial system and reproductive tract to oestrogen in the male mouse. J Endocrinol 37:17-21

Nicol T, Vernon-Roberts B, Quantock DC (1965a) The influence of various hormones on the reticulo-endothelial system: endocrine control of body defense. J Endocrinol 33:365-383

Nicol T, Vernon-Roberts B, Quantock DC (1965b) Protective effect of oestrogens against the toxic decomposition products of tribromoethanol. Nature 208:1098-1099

Nicol T, Vernon-Roberts B (1963) The distribution of lipoid and glycogen in the uterine horns of the ferret during the oestrous cycle. J Obst Gynaec Brit Commonwealth 70:851-858

Osti OL, Fraser RD, Vernon-Roberts B (1990a) Discitis after discography. The role of prophylactic antibiotics. J Bone Joint Surg Br 72:271-274

Osti OL, Vernon-Roberts B, Fraser RD (1990b) 1990 Volvo Award in experimental studies. Anulus tears and intervertebral disc degeneration. An experimental study using an animal model. Spine (Phila Pa 1976) 15:762-767

Osti OL, Vernon-Roberts B, Moore R, Fraser RD (1992) Annular tears and disc degeneration in the lumbar spine. A post-mortem study of 135 discs. J Bone Joint Surg Br 74:678-682

Pieterse AS, Vernon-Roberts B, Paterson DC, Cornish BL, Lewis PR (1983) Osteoid osteoma transforming to aggressive (low grade malignant) osteoblastoma: a case report and literature review. Histopathology 7:789-800

Pollock DJ, Vernon-Roberts B (1971) Granular-cell myoblastoma of the bronchus. J Pathol 103(2): Pv

Rainsford KD, Whitehouse MW, Vernon-Roberts B (1995) Effects of prostaglandin E-1 analogue, misoprostol, on the development of adjuvant arthritis in rats. Inflammapharmacol 3:49-63

Revell PA, Dean MF, Vernon-Roberts B, Muir H, Marshall AH (1972) Inhibition of macrophage migration by a proteoglycan extracted from Kurloff cells of the guinea-pig. Int Arch Allergy Appl Immunol 43:813-825

Revell PA, Vernon-Roberts B, Gray A (1971) The distribution and ultrastructure of the Kurloff cell in the guinea-pig. J Anat 109:187-199

Rofe AM, Whitehouse MW, Bourgeois CS, Haynes DR, VernonRoberts B (1990) Prevention of adjuvant-induced cachexia in rats by cyclosporin A. Immunol Cell Biol 68(Pt 1):63-69

Shimamura Y, Holding C, Haynes DR, Vernon-Roberts B, Blumbergs PC, Fraser RD, Moore RJ (2008a) The biologic response to particles from a potential disc prosthesis material. Spine (Phila Pa 1976) 33:351-355

Shimamura Y, Kaneko K, Vernon-Roberts B, Yazawa Y (2008b) Management of a large lesion of monostotic fibrous dysplasia with possible malignant transformation. Eur J Orthop Surg Traumatol 18:467-470

Shimamura Y, Vernon-Roberts B, Kaneko K, Arai Y, Muta T, Anami Y, Iwase H (2008c) Novel diagnosis and subsequent management of a very large giant cell tumour of bone arsing as a rarity iin the thoracic spine. Eur J Orthop Surh Traumatol 18:371-375

Thomas DW, Phillips PJ, Hooper MJ, Harding PE, Steele PM, Seymour A, Vernon-Roberts B, Robertson A (1979) Comparison of histological, radiological and biochemical indexes of bone mass and turnover. Aus M NZ J Med 9:92

Turnbull A, Baker H, Vernon-Roberts B, Magnus IA (1973) Iron metabolism in porphyria cutanea tarda and in erythropoietic protoporphyria. Q J Med 42:341-355

Utteridge TD, Gebski V, Finnie JW, Vernon-Roberts B, Kuchel TR (2002) Long-term exposure of E-mu-Pim1 transgenic mice to 898.4 MHz microwaves does not increase lymphoma incidence. Radiat Res 158:357-364

Vernon-Roberts B (1969a) The effects of steroid hormones on macrophage activity. Int Rev Cytol 25:131-159
Vernon-Roberts B (1969b) Lymphocyte to macrophage transformation in the peritoneal cavity preceding the mobilization of peritoneal macrophages to inflamed areas. Nature 222: $1286-1288$

Vernon-Roberts B (1969c) The effects of steroid hormones on macrophage function. In: Bourne GH, Danielle JF (eds) International Review of Cytology, vol 25. Academic Press, New York, pp 131-160

Vernon-Roberts B (1972) Biological structure and function vol 2. The macrophage. In: Biological Structure and Function. The Macophage, p 242

Vernon-Roberts B (1973) Proceedings: clinical and diagnostic importance of synovial fluid examination. J Clin Pathol 26:982

Vernon-Roberts B (1978a) Prosthetic implant reactions. Aus NZ J Med 8:159-162

Vernon-Roberts B (1978b) Prosthetic implant reactions. Aust N Z J Med 8(Suppl 1):159-162

Vernon-Roberts B (1978c) Synovial pathophysiology-diagnostic features and their standardisation. Aust N Z J Med 8(Suppl 1):16-19

Vernon-Roberts B (1979a) Actions of gold salts on the inflammatory response and inflammatory cell-function. $\mathrm{J}$ Rheumatol $6: 120-129$

Vernon-Roberts B (1979b) Action of gold salts on the inflammatory response and inflammatory cell function. J Rheumatol Suppl 5:120-129

Vernon-Roberts B (1979c) Morphological and functional interrelationships of bone cells and matrix. Aust $\mathrm{N} Z \mathrm{~J}$ Med 9:1-8

Vernon-Roberts B (1979d) Pathology of rheumatoid disease. Med J Aust 1:4-6

Vernon-Roberts B (1984) Vertebral rim lesions in dorsolumbar spine. Ann Rheum Dis 43:662

Vernon-Roberts B (1988) Inflammation 1987: an overview. Agents Actions Suppl 24:1-18

Vernon-Roberts B (1994) Christian Georg Schmorl. Pioneer of spinal pathology and radiology. Spine (Phila Pa 1976) 19:2724-2727

Vernon-Roberts B (1996) Eosinophilic synovitis. J Bone Joint Surg Br 78:682-683

Vernon-Roberts B, Darracott J (1981) Unusual Features observed in pathological studies of sacro-iliac joints from subjects with and without connective-tissue diseases. Aus NZ J Med 11:714

Vernon-Roberts B, Jessop JD (1972) Effects of gold and prednisolone on inflammation and phagocytosis in the rat. Ann Rheum Dis 31:536-537

Vernon-Roberts B, Pirie CJ (1973) Healing trabecular microfractures in the bodies of lumbar vertebrae. Ann Rheum Dis 32:406-412

Vernon-Roberts B, Pirie CJ (1977) Degenerative changes in the intervertebral discs of the lumbar spine and their sequelae. Rheumatol Rehabil 16:13-21

Vernon-Roberts B, Jessop JD, Dore J (1973) Effects of gold salts and prednisolone on inflammatory cells. II. Suppression of inflammation and phagocytosis in the rat. Ann Rheum Dis 32:301-307

Vernon-Roberts B, Currey HL, Perrin J (1974a) T and B cells in the blood and synovial fluid of rheumatoid patients. Ann Rheum Dis 33:430-434

Vernon-Roberts B, Pirie CJ, Trenwith V (1974b) Pathology of the dorsal spine in ankylosing hyperostosis. Ann Rheum Dis $33: 281-288$

Vernon-Roberts B, Liyanage SP, Currey HL (1975) Adjuvant arthritis in the rat. Distribution of fluorescent material after footpad injection of rhodamine-labelled tubercle bacilli. Ann Rheum Dis 35:389-397

Vernon-Roberts B, Dore JL, Jessop JD, Henderson WJ (1976) Selective concentration and localization of gold in macrophages of synovial and other tissues during and after chrysotherapy in rheumatoid patients. Ann Rheum Dis 35:477-486 
Vernon-Roberts B, Barnes CG, Revell PA (1978) Synovial pathology in Behcet's syndrome. Ann Rheum Dis 37:139-145

Vernon-Roberts B, McNamara PJ, Jones AN (1979) Osteoporosis and micro-fractures. Aus NZ J Med 9:94

Vernon-Roberts B, Cleary E, Vernon-Roberts J (1997a) Graded check list to assist undergraduate students in self-directing learning and assessment in general systematic anatomical pathology. Pathology 29:370-373

Vernon-Roberts B, Fazzalari NL, Manthey BA (1997b) Pathogenesis of tears of the anulus investigated by multiple-level transaxial analysis of the T12-L1 disc. Spine(Phila Pa 1976) 22:2641-2646

Vernon-Roberts B, Moore RJ, Fraser RD (2007) The natural history of age-related disc degeneration: the pathology and sequelae of tears. Spine (Phila Pa 1976) 32:2797-2804

Vernon-Roberts B, Moore RJ, Fraser RD (2008) The natural history of age-related disc degeneration: the influence of age and pathology on cell populations in the L4-L5 disc. Spine (Phila Pa 1976) 33:2767-2773

Walters R, Vernon-Roberts B, Fraser R, Moore R (2006) Therapeutic use of cephazolin to prevent complications of spine surgery. Inflammopharmacology 14:138-143

Whitehouse MW, Horewood AH, Vernon-Roberts B (1988) Variable responses to gold (I)-thiolates (chrysotherapy) in two models of rat polyarthritis. Agents Actions Suppl 24:184-188

Whitehouse MW, Rainsford KD, Taylor RM, Vernon-Roberts B (1990) Zinc monoglycerolate: a slow-release source of zinc with anti-arthritic activity in rats. Agents Actions 31:47-58

Whitehouse MW, Vernon-Roberts B (1991) Conditional pharmacology: expression of the anti-inflammatory activity may require pre-existent inflammatory mediators and/or hormones. Inflammopharmacology 1:61-68

Whitehouse MW, Vernon-Roberts B (2008) Revisiting the conditional concept for pathology, pharmacology and toxicology. Inflammopharmacology 16:294
Whitehouse MW, Vernon-Roberts B (1990) Misoprostol augments the anti-inflammatory activity of non-steroid corticosteroid and antioxidant drugs in rats. Arth Rheum 33:S110

Whitehouse MW, Vernon-Roberts B (1985) Oxicams some extra pharmacological properties demonstrable in rats. Aust NZ J Med 15:194

Whitehouse MW, Garrett IR, Vernon-Roberts B, Brooks PM (1982a) Ambivalent effects of anti-arthritic gold drugs on experimental polyarthritis in rats. Intl J Immunopharm 4:325

Whitehouse MW, Garrett IR, Vernon-Roberts B, Brooks PM (1982b) Ambivalent effects of anti-arthritic gold drugs on experimental poly arthritis in rats. Arth Rheum 25:S129

Wicks M, Garrett R, Vernon-Roberts B, Fazzalari N (1982) Absence of metabolic bone disease in the proximal femur in patients with fracture of the femoral neck. J Bone Joint Surg Br 64:319-322

Wiebkin OW, Myers DB, Vernon-Roberts B (1982) Sponge-induced granuloma developments in rats -effect of prednisolone. Conn Tiss Res 9:216

Wilby MJ, Fraser RD, Vernon-Roberts B, Moore RJ (2009) The prevalence and pathogenesis of synovial cysts within the ligamentum flavum in patients with lumbar spinal stenosis and radiculopathy. Spine (Phila Pa 1976) 34:2518-2524

Wilksch J, Vernon-Roberts B, Garrett R, Smith K (1983) The role of catheter surface morphology and extractable cytotoxic material in tissue reactions to urethral catheters. Br J Urol 55:48-52

Woodland J, Currey HL, Vernon-Roberts B (1977a) The effect of anti-inflammatory and antirheumatic drugs on inflammation in the rat. Curr Med Res Opin 5:3-10

Woodland J, Vernon-Roberts B, Swettenham KV, Currey HL (1977b) Comparison of the effects of alclofenac, flurbiprofen, and prednisolone on acute inflammatory response in the rat. Ann Rheum Dis 36:160-165 